\title{
Pengaruh Jenis dan Dosis Mulsa Terang bulan dan Kirinyuh Terhadap Pertumbuhan Gulma pada Tanaman Kedelai (Glycine $\max$ L.)
}

The Effect of Sun Weed Flower and Siam Weed Dose and Species toward the Weeds Growth to Soybean Plant (Glycine max L.)

\author{
Syuhada ${ }^{1}$, Gina Erida ${ }^{1}$, Hasanuddin ${ }^{1 *}$ \\ ${ }^{1}$ Program Studi Agroteknologi, Fakultas Pertanian, Universitas Syiah Kuala
}

\begin{abstract}
Abstrak. Pengendalian gulma merupakan suatu usaha guna menekan pertumbuhan gulma, tetapi tidak berpengaruh negatif terhadap tanaman budidaya. Kehadiran gulma di antara tanaman budidaya dapat menyebabkan persaingan dalam hal memperbutkan air, unsur hara, cahaya dan ruang tumbuh. Penelitian ini bertujuan untuk mengetahui pengaruh berbagai mulsa gulma terhadap perubahan komposisi gulma pada tanaman kedelai. Penelitian ini dilaksanakan di Desa Rumpeet, Kecamatan Krueng Barona Jaya, Aceh Besar dan di Laboratorium Ilmu Gulma Fakultas Pertanian Universitas Syiah Kuala, Banda Aceh yang dilaksanakan pada Januari sampai April 2018. Bahan yang digunakan adalah benih kedelai Dega-1 yang diperoleh dari Balai Penelitian Tanaman Aneka Kacang dan Umbi (Balitkabi) Malang. Rancangan percobaan yang dilakukan dalam penelitian ini adalah rancangan acak kelompok (RAK) fola faktorial 2 x 4 dengan 3 ulangan. Hasil penelitian menunjukkan bahwa jenis dan dosis mulsa tidak berpengaruh terhadap jumlah spesies gulma dan jumlah populasi gulma. Terdapat interaksi antara jenis dan dosis mulsa pada jumlah spesies gulma 56 Hari Setelah Tanam (HST).
\end{abstract}

Kata kunci : Gulma, Terang bulan, Kirinyuh dan Kedelai.

\begin{abstract}
Abstrack. Weed controling is one of some step to attempt weed growth, but does not have any negatif effect to cultivated plants. The precense of weed among the cultivated plants can lead to competition in term of competing for waters, nutrients, lights and growing space. This research is aims to determine the effect of some weed mulch for weed alteration on soybean. This research was held in umpeet Village, Subdistric of Krueng Barona Jaya, Aceh Besar Regency and Weed Science Laboratory, Faculty of Agriculture, University of Syiah Kuala. The materials used is soybeans seed variety of Dega-1 that collected from Balai Penelitian Tanaman Aneka Kacang dan Umbi (Balitkabi) Malang. This research using Randomize Block Design (RBD) factorial pattern $2 \times 4$ repeated 3 times. The result of this research showed that the mulch's species and dose were not affected by the number of weeds populations and species. There was an interaction between the mulch species and dose on weeds species number during 56 days after it was planted.
\end{abstract}

Keywords : Weeds, Mexican Sun Flower, Siam Weed and Soybeans

\section{PENDAHULUAN}

Suatu usaha mengubah keseimbangan ekologis yang bertujuan untuk menekan pertumbuhan gulma, tetapi tidak berpengaruh negatif terhadap tanaman budidaya merupakan definisi pengendalian gulma (Sukman dan Yakup, 2002). Beberapa faktor seperti varietas, curah hujan, kondisi tanah, kerapatan gulma, pertumbuhan gulma, serta umur tanaman saat gulma mulai bersaing mempengaruhi tingkat persaingan antara tanaman dengan gulma (Jatmiko et al., 2002). Menurut Sebayang (2004) penurunan hasil akibat gulma dapat mencapai $30-50 \%$ pada tanaman kedelai.

Chozin dan Sumantri (1983) menyatakan bahwa sistem pemulsaan merupakan salah satu metode yang dapat digunakan untuk mengendalikan gulma. Suatu material yang digunakan untuk menutupi permukaan tanah dengan tujuan mencegah kehilangan air akibat evaporasi dan menghambat pertumbuhan gulma 
disebut mulsa. Menurut Dwiyanti (2005) lebih lanjut menyatakan untuk mendukung pertumbuhan tanaman kedelai, salah satu teknik budidaya yang tepat diterapkan yaitu dengan cara pemulsaan. Mulsa yang bahannya berasal dari tumbuhan dan sisa tanaman pertanian disebut mulsa organik. Adapun beberapa tumbuhan yang berpotensi untuk dijadikan mulsa antara lain yaitu terang bulan, kirinyuh dan nimba.

Terang bulan (Tithonia diversifolia) merupakan tumbuhan yang dapat hidup pada berbagai kondisi lahan. Terang bulan tumbuh baik pada ketinggian 20 sampai 900 mdpl (Hakim, 2001). Menurut Hartatik (2007) bahwa tanaman terang bulan mempunyai senyawa fitotoksik yang dapat menghambat pertumbuhan beberapa jenis tanaman.

Kirinyuh (Chromolaena odorata) adalah tumbuhan yang berasal dari famili Compositae. Beberapa senyawa utama pada daun kirinyuh yaitu flavonoid, tanin, saponin, fenol dan steroid (Inya-agha et al., 1987). Menurut hasil penelitian Darana (2006) bahwa pertumbuhan gulma di perkebunan teh dapat dihambat menggunakan ekstrak daun kirinyuh. Pada konsentrasi 20\%, ekstrak daun kirinyuh mampu menekan pertumbuhan gulma yang lebih efisien dan berpengaruh nyata dibandingkan perlakuan penyiangan mekanis maupun penggunaan herbisida sintetis. Sedangkan hasil penelitian Susilowati (2012) menunjukkan bahwa pemberian ekstrak kirinyuh berpengaruh terhadap perkecambahan serta pertumbuhan bayam duri dengan penghambatan tertinggi pada konsentrasi $10 \%$.

Biji gulma tidak memperoleh sinar matahari yang cukup bila hamparan mulsa disebar di atas permukaan tanah. Pertumbuhan gulma akan terhalang akibat rendahnya intensitas cahaya yang diterima. Sehingga tanaman utama tumbuh bebas tanpa kompetisi dengan gulma dalam menyerap air dan unsur hara. Pemberian mulsa juga dapat menghambat laju pertumbuhan gulma (Lakitan, 1995). Moenandir (1988) menyatakan penurunan produksi akibat gulma di sekitar pertanaman kedelai berkisar antara $30-50 \%$.

Hasil penelitian pada pertanaman kedelai menunjukkan bahwa jenis mulsa organik berpengaruh terhadap jumlah spesies gulma pada umur 42 HST dan saat panen. Dosis mulsa berpengaruh terhadap jumlah spesies gulma pada seluruh waktu pengamatan. Semakin tinggi pemberian dosis mulsa organik, maka semakin rendah jumlah populasi gulma pada setiap jenis mulsa (Abdillah, 2018). Selanjutnya hasil penelitian Sultani (2017) menyatakan dosis mulsa organik kirinyuh berpengaruh terhadap jenis gulma pada 7 dan 9 MST, persentase penutupan gulma 3, 5 dan 7 MST serta bobot kering gulma 3 MST. Dosis mulsa kirinyuh 18 ton $\mathrm{ha}^{-1}$ dapat menurunkan jenis gulma, popuasi gulma, persentase penutupan gulma serta bobot kering gulma. Berdasarkan penjelasan di atas maka perlu dilakukan penelitian lebih lanjut mengenai pengaruh pemberian mulsa terhadap pertumbuhan gulma.

\section{METODOLOGI PENELITIAN}

\section{Tempat dan Waktu Penelitian}

Penelitian ini dilaksanakan di Desa Rumpeet, Aceh Besar dan di Laboratorium Ilmu Gulma Fakultas Pertanian Universitas Syiah Kuala, Banda Aceh. Penelitian ini berlangsung dari Januari-April 2018. 


\section{Alat dan Bahan Penelitian}

Bahan tanam yang digunakan dalam penelitian ini adalah benih kedelai varietas Dega-1 yang didapat dari Balai Penelitian Tanaman Aneka Kacang dan Umbi (Balitkabi), Malang, mulsa terang bulan, kirinyuh dan nimba. Pupuk yang digunakan yaitu urea, SP36 dan $\mathrm{KCl}$, dan insektisida Deltametrin. Alat-alat yang digunakan yaitu: handtractor, cangkul, meteran, ember, parang, gembor, tali ravia, alat tulis, kerangka besi (frame) ukuran $50 \mathrm{~cm}$ x $50 \mathrm{~cm}$, oven, timbangan duduk (Y.M.C.CO 10 kg), dan timbangan analitik (Max 1000 g, d. 0,5 g).

\section{Rancangan Penelitian}

Penelitian ini menggunakan Rancangan Acak Kelompok (RAK) pola faktorial $2 \times 4$ dengan 3 ulangan. Faktor pertama yaitu jenis mulsa terang bulan dan kirinyuh dengan 2 taraf dan faktor kedua yaitu dosis mulsa 4 taraf sehingga diperoleh 8 kombinasi perlakuan dan 24 unit percobaan.

\section{Prosedur Penelitian \\ Persiapan Lahan}

Sebelum tanah diolah, dilakukan analisis vegetasi gulma terlebih dahulu dengan menghitung jumlah populasi dan jumlah individu gulma menggunakan metode kuadrat plot $50 \mathrm{~cm}$ x $50 \mathrm{~cm}$. Lahan diolah menggunakan handtractor. Selanjutnya lahan diolah manual menggunakan cangkul. Kemudian dibuat petakan bedeng dengan ukuran 3 x 2,5 m sebanyak 36 petakan dengan jarak drainase antar perlakuan $30 \mathrm{~cm}$ dan antar ulangan $50 \mathrm{~cm}$.

\section{Persiapan Penanaman}

Penanaman benih pada setiap bedeng dilakukan dengan teliti. Benih yang digunakan memiliki karakter fisik baik meliputi bersih dari kotoran, keutuhan kulit dan ukuran yang seragam. Pembuatan lubang tanam dengan cara ditugal sedalam $2 \mathrm{~cm}$, dimasukkan benih kedalam lubang tanam terdiri dari 4 benih bersamaan dengan furadan sekitar 5 butir per tanaman dengan jarak tanam $30 \mathrm{~cm}$ x $30 \mathrm{~cm}$ dan ditutup dengan tanah. Sebelum dilakuan penanaman benih kedelai terlebih dahulu diberi rhizobium yang berasal dari tanah bekas pertanaman kedelai. Tanah yang telah disiapkan kemudian dicampur dengan benih kedelai lalu diaduk merata. Setelah tanaman tumbuh kemudian dilakukan pengurangan pada saat umur 10 HST menjadi 2 tanaman per lubang.

\section{Pemupukan}

Pupuk yang digunakan adalah SP36, Urea, $\mathrm{KCl}$ dengan dosis pupuk yaitu urea $50 \mathrm{~kg} \mathrm{ha}^{-1}=37,5 \mathrm{~g} \mathrm{plot}^{-1}, \mathrm{SP} 3660 \mathrm{~kg} \mathrm{ha}^{-1}=48 \mathrm{~g} \mathrm{plot}^{-1}$ dan $\mathrm{KCl} 70 \mathrm{~kg} \mathrm{ha}^{-1}=$ $52,5 \mathrm{~g} \mathrm{plot}^{-1}$. Pemupukan dilakukan secara bertahap, yaitu urea diberikan setengah bagian pada saat tanam dengan cara mencampurkan ketiga pupuk tersebut, dan yang setengah bagian berikutnya diberikan 30 hari setelah tanam (HST). Pemberian pupuk dilakukan dengan cara larikan.

\section{Aplikasi Mulsa}

Jenis mulsa terang bulan diperoleh dari Desa Toweren, Kecamatan Lot Tawar, Kabupaten Aceh Tengah. Kirinyuh diperoleh dari kawasan Desa Limpok, Kecamatan Syiah Kuala, Kabupaten Aceh Besar. Pengambilan mulsa terang bulan 
dilakukan dengan mencabut sampai ke akar lalu nanti pada saat pengaplikasian bagian yang digunakan hanya bagian batang yang memiliki daun dengan panjang sekitar $50 \mathrm{~cm}$. Mulsa kirinyuh dilakukan dengan cara memotong pada bagian batang dari pucuk daun $20 \mathrm{~cm}$. Pengaplikasian mulsa dilakukan pada saat tanam setelah pemberian pupuk dan penanaman benih. Untuk kebutuhan mulsa terang bulan dan kirinyuh setelah dikonversi ke plot yaitu $D_{1}=6 \mathrm{~kg} \mathrm{plot}^{-1}, \mathrm{D}_{2}=12 \mathrm{~kg}$ plot $^{-1}$ dan $\mathrm{D}_{3}=18 \mathrm{~kg}$ plot $^{-1}$. Total terang bulan dan kirinyuh yang dibutuhkan adalah $216 \mathrm{~kg}$.

\section{Pemeliharaan}

Pemeliharaan yang dilakukan meliputi: penyiraman, pengendalian hama dan penyakit. Penyiraman dilakukan pagi dan sore hari. Pengendalian hama dilakukan menggunakan insektisida Deltametrhin dengan konsentrasi larutan $2 \mathrm{cc}$ $\mathrm{L}^{-1}$ air. Penyemprotan insektisida dilakukan pada sore hari.

\section{Pemanenan}

Pemanenan tanaman kedelai dilakukan pada saat umur 75 HST. Ciri-ciri tanaman kedelai sudah dapat dipanen yaitu karakteristik sebagian besar daun sudah menguning atau polong sudah kelihatan tua, serta batang bewarna kecoklatan.

\section{Parameter Pengamatan}

Parameter yang diamati adalah jumlah spesies gulma dan jumlah populasi gulma

\section{Analisis Data Penelitian}

Data hasil pengamatan pada setiap parameter dianalisis dengan anova. Data yang menunjukkan perbedaan yang nyata pada Fhitung maka dilanjutkan dengan uji Duncan New Multiple Range Test (DNMRT) pada taraf 0,05.

\section{PEMBAHASAN}

\section{Jumlah Spesies Gulma}

Hasil analisis ragam menunjukkan bahwa jenis dan dosis mulsa tidak berpengaruh terhadap jumlah spesies gulma pada 28 HST. Terdapat interaksi antara jenis dan dosis mulsa terhadap jumlah spesies gulma pada 56 HST. Ratarata jumlah spesies gulma akibat aplikasi jenis dan dosis mulsa masing-masing dapat dilihat pada Tabel 1, sedangkan interaksi antara aplikasi jenis dan dosis mulsa pada Tabel 2.

Tabel 1. Rata-rata jumlah spesies gulma akibat aplikasi jenis dan dosis mulsa

\begin{tabular}{cc}
\hline \multirow{2}{*}{ Perlakuan } & Jumlah Spesies Gulma (Jenis) \\
\cline { 2 - 2 } & 28 HST \\
\hline Jenis Mulsa & \\
Terang Bulan & 8,75 \\
Kirinyuh & 8,42 \\
\hline
\end{tabular}

Dosis $\left(0\right.$ ton $\left.\mathrm{ha}^{-1}\right)$ 


\begin{tabular}{cc}
0 & 8,33 \\
8 & 8,17 \\
16 & 8,83 \\
24 & 9,00 \\
\hline
\end{tabular}

Tabel 1 menunjukkan bahwa jenis dan dosis mulsa tidak berpengaruh terhadap jumlah spesies gulma pada pengamatan 28 HST. Hal ini di karenakan faktor jenis mulsa itu sendiri yang mengalami pelapukan setelah kedelai berumur 28 hari. Dari hasil pengamatan di lapangan menunjukkan bahwa mulsa terang bulan dan kirinyuh sudah mengalami degradasi setelah 3 hari aplikasi. Fenomena ini menyebabkan cahaya matahari mampu menembus permukaan tanah sehingga gulma dapat berkecambah dan tumbuh dengan baik. Seperti dijelaskan oleh Damaiyanti et al. (2012) bahwa pertumbuhan gulma sangat dipengaruhi oleh kondisi lingkungan yaitu penyinaran dan naungan

Tabel 2. Rata-rata jumlah spesies gulma pada 56 HST akibat interaksi antara jenis dan dosis mulsa

\begin{tabular}{|c|c|c|c|c|c|c|c|c|}
\hline \multirow{3}{*}{ Perlakuan } & \multicolumn{8}{|c|}{ Jumlah spesies gulma (jenis) } \\
\hline & \multicolumn{8}{|c|}{ Dosis $\left(\right.$ ton $\left.\mathrm{ha}^{-1}\right)$} \\
\hline & 0 & & 8 & & 16 & & 24 & \\
\hline Terang Bulan & 10,33 & $\mathrm{Ba}$ & 7,33 & $\mathrm{Aa}$ & 11,00 & $\mathrm{Cb}$ & 7,33 & $\mathrm{Aa}$ \\
\hline Kirinyuh & 10,00 & $\mathrm{Ba}$ & 8,33 & $\mathrm{Ab}$ & 8,33 & $\mathrm{Aa}$ & 8,33 & $\mathrm{Ab}$ \\
\hline
\end{tabular}

Tabel 2 menunjukkan bahwa dosis $8-24$ ton $\mathrm{ha}^{-1}$ mampu menurunkan jumlah spesies gulma pada setiap perlakuan jenis mulsa. Hal ini menunjukkan bahwa semakin tinggi dosis yang diberikan maka permukaan tanah yang tertutupi oleh mulsa akan semakin tebal. Intensitas cahaya yang masuk ke permukaan tanah akan terhalang oleh mulsa dan dapat menghambat perkecambahan serta pertumbuhan gulma. Fenomena ini mengakibatkan terhalangnya pertumbuhan gulma sehingga jumlah spesies gulma menurun. Smith dan Alli (2007) membuktikan bahwa pemberian mulsa kirinyuh dengan dosis 24 ton ha ${ }^{-1}$ mampu menurunkan jenis gulma yang dapat menembus permukaan mulsa.

Sukman dan Yakup (2002) menyatakan kecambah-kecambah gulma dan beberapa jenis gulma dewasa akan mati akibat pemberian mulsa dikarenakan cahaya yang tidak mampu menembus permukaan tanah. Prasetyo (2014) menambahkan terjadi persaingan yang tinggi dengan gulma bila suatu lahan budidaya tidak diberi perlakuan mulsa.

\section{Jumlah Populasi Gulma}

Hasil analisis ragam menunjukkan bahwa jenis dan dosis mulsa tidak berpengaruh terhadap jumlah populasi gulma pada pengamatan 28 dan 56 HST. Rata-rata jumlah populasi gulma akibat aplikasi jenis dan dosis mulsa masingmasing dapat dilihat pada Tabel 3 . 
Tabel 3 Rata-rata jumlah populasi gulma akibat aplikasi jenis dan dosis mulsa

\begin{tabular}{ccc}
\hline \multirow{2}{*}{ Perlakuan } & \multicolumn{2}{c}{ Jumlah Populasi Gulma (Jenis) } \\
\cline { 2 - 3 } & 28 HST & 56 HST \\
\hline Jenis Mulsa & & \\
Terang Bulan & 67,83 & 57,92 \\
Kirinyuh & 58,42 & 45,83 \\
\hline Dosis $\left(0\right.$ ton ha $\left.^{-1}\right)$ & & \\
0 & 74,33 & 62,17 \\
8 & 55,00 & 59,50 \\
16 & 62,33 & 45,50 \\
24 & 60,83 & 40,33 \\
\hline
\end{tabular}

Jenis dan dosis mulsa tidak berpengaruh terhadap jumlah populasi gulma (Tabel 3). Faktor biologis jenis mulsa sangat mempengaruhi pertumbuhan gulma. Dari hasil pengamatan di lapangan menunjukkan bahwa mulsa yang di aplikasikan setelah 3 hari mulai mengalami pelapukan. Terdegradasinya mulsa menyebabkan cahaya matahari mampu menembus permukaan tanah sehingga merangsang biji gulma untuk tumbuh dan berkecambah. Fenomena ini menyebabkan pemberian dosis yang semakin besar juga tidak akan mempengaruhi jumlah populasi gulma. Fenomena ini sama dengan pernyataan Purwowidodo (1983) bahwa salah satu kegunaan mulsa adalah menghalangi intensitas cahaya ke permukaan tanah. Mulsa juga dapat mempengaruhi temperatur tanah. Sesuai dengan pernyataan Mahmood et al. (2002) menambahkan temperatur tanah berhubungan dengan proses fotosintesis, respirasi dan penyerapan unsur hara oleh akar tanaman

\section{KESIMPULAN}

Jenis dan dosis mulsa tidak berpengaruh terhadap jumlah spesies gulma dan jumlah populasi gulma. Terdapat interaksi antara jenis dan dosis mulsa pada jumlah spesies gulma 56 HST.

\section{DAFTAR PUSTAKA}

Abdillah M. P. 2018. Perubahan komposisi gulma akibat jenis dan dosis mulsa organik gulma kirinyuh dan nimba pada tanaman kedelai (Glycine max L.). Skripsi. $\quad$ Fakultas Pertanian Universitas Syiah Kuala.

Chozin, M.A. dan Sumantri. 1983. Pengendalian gulma dengan mulsa dan herhisida pratumbuh pada tanaman jagung (Zea mays L.). Bull. Agronomi. XIV (2) Fakultas Pertanian IPB, Bogor.

Damaiyanti, D.R.R., N. Aini dan Koesriharti. 2012. Kajian penggunaan macam mulsa organik pada pertumbuhan dan hasil tanaman cabai besar (Capsicum annuиm L.). J. Produksi Tanaman. 1 (2) : 25-32.

Darana, S. 2006. Aktivitas alelopati ekstrak daun kirinyuh (Chromolaena odorata) dan saliara (Lantana camara) terhadap gulma di pertanaman teh (Camelia sinensis). J. Penelitian Teh dan Kina 9 (1-2) : $15-20$. 
Dwiyanti, S. 2005. Respon pengaturan ketebalan mulsa jerami padi dan jumlah pemberian air pada pertumbuhan dan hasil tanaman kacang hijau. J. Floratek. $16(6)$ : 192-201.

Hakim, N. 2001. Kemungkinan penggunaan Thithonia (Tithonia diversifolia A. Gray)sebagai bahan organik dan nitrogen. Laporan P3 IN. UNAND. Padang.

Hartatik, W. 2007. Tithonia diversifolia sebagai pupuk hijau. Warta Penelitian dan Pengembangan Pertanian. 29 (5) : 3-5.

Inya-agha, S.I., B.O. Oguntimein, A. Sofowora dan V.T. Benjamin. 1987. Phytochemical and antibacterial studies on the essential oil of eupatorium odoratum. International Journal Crude Drug Research. 25 (1) : 49-52.

Jatmiko, S.Y., S. Harsanti, Sarwoto dan A.N. Ardiwinata. 2002. Apakah herbisida yang digunakan cukup aman? hal. 337-348. Dalam J. Soejitno, I.J. Sasadan Hermanto (Eds.). Prosiding Seminar Nasional Membangun Sistem Produksi Tanaman Pangan Berwawasan Lingkungan. Pusat Penelitian dan Pengembangan Tanaman Pangan. Bogor.

Lakitan, B. 1995. Hortikultura I, Teori Budidaya dan Pasca Panen. Jakarta: Raja Grafindo Persada.

Mahmood, M., K. Farroq, A. Hussain, R. Sher. 2002. Effect of mulching on growth and yield potato crop. Asian J. Of Plant Sci. 1 (2) : 122-133.

Moenandir, J. 2010. Persaingan Tanaman Budidaya dengan Gulma. Jakarta: Rajawali Press.

Prasetyo, R. A., A. Nugroho dan J. Moenandir. 2014. Pengaruh sistem olah tanah dan berbagai mulsa organik pada pertumbuhan dan hasil tanaman kedelai (Glycine max L. Merr.) Var. Grobogan. J. Produksi Tanaman. 1 (6) : 486495.

Purwowidodo. 1983. Teknologi Mulsa. Jakarta: Dwi Suci Press.

Sebayang, H.T. 2004. Herbisida dan Pengendalian Gulma Tanaman. Fakultas Pertanian- Universitas Brawijaya. Malang. Hal. 75.

Smith, M.A.K., and A.L. Alli. 2007. Mulching of tropical plant resudues on ecological weed growth in maize (Zea mays L.). African Crop Science Conference proceedings. Vol. $8: 1105-1115$.

Sukman, Y. dan Yakup. 2002. Gulma dan Teknik Pengendaliannya. Jakarta: PTGrafindo Persada.

Sultani. 2017. Pengaruh dosis dan waktu aplikasi mulsa organik kirinyuh (Chromolaena odorata) terhadap perkembangan gulma dan hasil tanaman kedelai (Glycine max L.). Skripsi. Fakultas Pertanian Universitas Syiah Kuala.

Susilowati, E. 2012. Perkecambahan dan pertumbuhan gulma bayam duri pada pemberian ekstrak kirinyuh. Skripsi. Jurusan Biologi FMIPA Universitas Sebelas Maret. Surakarta. 